\title{
Metronidazole: A Corrosion Inhibitor for Mild Steel in Aqueous Environment
}

\author{
S.M. Megalai, ${ }^{a,{ }^{*}}$ P. Manjula, ${ }^{b}$ K.N. Manonmani, ${ }^{c}$ N. Kavitha $^{a}$ and N. Baby ${ }^{d}$ \\ ${ }^{a} P G$ and Research Department of Chemistry, Arulmigu Palaniandavar College of Arts \& Culture, Palani-624601, \\ Tamilnadu, India \\ ${ }^{b}$ Arulmigu Palaniandavar College for Women, Palani-624601, Tamilnadu, India. \\ ${ }^{c}$ Sri Subramaniya College of Engineering \& Technology, Palani-624601, Tamilnadu, India. \\ ${ }^{d}$ Christian College of Engineering, Oddanchathiram, Tamilnadu, India
}

Received 2 November 2012; accepted 23 December 2012

\begin{abstract}
The inhibition efficiency (IE) of metronidazole (MZ)-Zn(II) system in controlling corrosion of mild steel in aqueous solution containing $60 \mathrm{ppm}$ of $\mathrm{Cl}^{-}$ion has been evaluated by weight loss method. Weight loss study reveals that the formulation consisting of $140 \mathrm{ppm}$ of $\mathrm{MZ}$ and $50 \mathrm{ppm}$ of $\mathrm{Zn}$ (II) has $84 \%$ inhibition efficiency in controlling corrosion of mild steel immersed in aqueous solution containing $60 \mathrm{ppm}$ of $\mathrm{Cl}^{-}$ion. Polarization study reveals that this system as a mixed type of inhibitor controlling the cathodic and anodic reaction to an equal extent. AC impedance reveals that a protective film is formed on the metal surface. The FTIR spectra revealed that the protective film consists of $\mathrm{Fe}(\mathrm{II})-\mathrm{MZ}$ complex.
\end{abstract}

Keywords: metronidazole drug, mild steel, corrosion inhibition, weight loss, polarization and $\mathrm{AC}$ impedance.

\section{Introduction}

Corrosion inhibition of mild steel is a matter of theoretical as well as practical importance [1]. It has been widely used in industries such as pickling, cleaning, descaling, etc., and because of their aggressiveness, inhibitors are used to reduce the dissolution of metals. Many organic hetero cyclic compounds containing $\mathrm{N}$, $\mathrm{S}, \mathrm{O}, \& \mathrm{P}$ have been reported as inhibitors [2-6].

A large number of organic compounds have been used as corrosion inhibitors for mild steel and most of them are highly toxic to both human beings and environment. Due to the increasing environmental awareness and the negative effects of some chemicals, research activities in recent times are geared towards developing the less toxic and environmentally safe corrosion inhibitors [7-12].

\footnotetext{
* Corresponding author. E-mail: mani_megalai22@yahoo.in
} 
It has been investigated [13] that some drugs like tryptamine, succinic acid, Lascorbic acid, sulfamethaxazole, cefratrexyl, cefradroxil and alpendazole were effective and eco-friendly inhibitors for acid environments. The inhibitive effect in acidic media through complex formation on metal surfaces by anti-bacterial drugs, namely ampicillin, cloxacillin, flucloxacillin and amoxicillin on controlling corrosion of Al was investigated [14].

Metronidazole is the commercial name for 2-methyl-5-nitro - imidazole -1ethanol having molecular formula $\mathrm{C}_{6} \mathrm{H}_{9} \mathrm{O}_{3} \mathrm{~N}_{2}$. Molecular weight of the metronidazole is 171.16. It is one of the azole group of anti-microbial agent and chemical structure as shown in Fig. 1, which is effective against anerobic microorganisms including gram positive, gram - negative, cocci and bacilli [15]. Metronidazole has been widely used in the treatment of trichomoniasis, amoebiasis, giardiasis, vincent infections and eradications of cysts.

Many literature reviews revealed the corrosion inhibitive effect on mild steel in acidic media. Even though many drugs have been used as corrosion inhibitors, the mechanistic aspects of corrosion inhibition in aqueous media have not been studied in detail. The present work is undertaken a) to evaluate the inhibition efficiency ( IE) of metronidazole in controlling the corrosion of mild steel in aqueous solution containing $60 \mathrm{ppm}$ of $\mathrm{Cl}^{-}$ion in the absence and presence of $\mathrm{Zn}^{2+}$ ion, b) to examine the influence of $\mathrm{pH}$ and duration of immersion on the IE of $\mathrm{MZ}$ drug, c) to analyze the protective film formed on the mild steel by FTIR spectra, d) to understand the mechanistic aspects of corrosion inhibition by potentiodynamic polarization and $\mathrm{AC}$ impedance analysis.<smiles>Cc1ncc([N+](=O)[O-])n1CCO</smiles>

Figure 1. Structure of metronidazole.

\section{Experimental methods}

\section{Inhibitor}

Stock solution of metronidazole in ppm level was made in DD water and used as corrosion inhibitor in the present study.

\section{Preparation of the specimens}

Mild steel specimens $(0.026 \% \mathrm{~S}, 0.06 \% \mathrm{P}, 0.4 \% \mathrm{Mn}, 0.1 \% \mathrm{C}$ and rest iron) of the dimensions $1.0 \times 4.0 \times 0.2 \mathrm{~cm}$ were polished to a mirror finish, degreased with trichloroethylene, and used for the weight- loss method and surface examination studies.

\section{Weight-loss method}

Mild steel specimens were immersed in $100 \mathrm{~mL}$ of a solution containing $60 \mathrm{ppm}$ of $\mathrm{Cl}^{-}$ion and various concentrations of the inhibitor in the presence and absence of $\mathrm{Zn}^{2+}$ ion for a period of one day. The weights of the specimens before and 
after immersion were determined using a balance, Schimadzu AY62 model. The inhibition efficiency (IE) was then calculated using the formula,

$$
\mathrm{IE}=100[1-(\mathrm{W} 2 / \mathrm{W} 1)] \%
$$

where $\mathrm{W} 1=$ corrosion rate in absence of the inhibitor and $\mathrm{W} 2=$ corrosion rate in presence of the inhibitor.

\section{Potentiodynamic polarization study}

This study was carried out using a CHI 660A electro chemical impedance analyzer model. A three-electrode cell assembly was used. The working electrode used was mild steel with $1 \mathrm{~cm}^{2}$ exposed area. A saturated calomel electrode (SCE) was used as reference electrode. A rectangular platinum foil was used as the counter electrode. Polarization curves were recorded after doing iR compensation. The parameters such as Tafel slopes, $\mathrm{I}_{\mathrm{Corr}}$ and $\mathrm{E}_{\mathrm{corr}}$ were calculated.

\section{AC impedance measurements}

A CHI 660A electro chemical impedance analyzer was used to record AC impedance measurements. The cell set up was the same as that used for polarization measurements. The real part $\left(Z^{\prime}\right)$ and imaginary part $\left(Z^{\prime \prime}\right)$ of the cell impedance were measured in Ohms for various frequencies. The Rt (charge transfer resistance) and $\mathrm{C}_{\mathrm{dl}}$ (double layer capacitance) were calculated.

\section{Surface examination study}

The mild steel specimens were immersed in various test solutions for a period of one day. After one day, the specimens were taken out and dried. The nature of the film formed on the surface of the metal specimens were analysed by surface analysis techniques such as FTIR spectra. The FTIR spectra were recorded with a Perkin- Elmer 1600 Spectrophotometer. The FTIR spectrum of the protective film was recorded by carefully removing the film mixing it with $\mathrm{KBr}$ and making the pellet.

\section{Results and discussion}

\section{Analysis of the results of weight-loss study}

The inhibition efficiency (IE) of metronidazole (MZ) drug, in controlling corrosion of mild steel in aqueous solution containing $60 \mathrm{ppm} \mathrm{of} \mathrm{Cl}^{-}$ion has been evaluated by weight-loss method.The results are given in Table 1. It is seen from Table 1 that when the mild steel is immersed in aqueous solution containing $60 \mathrm{ppm}$ of $\mathrm{Cl}^{-}$ion, the corrosion rate is $53.63 \mathrm{mdd}$, whereas when $20 \mathrm{ppm}$ of $\mathrm{MZ}$ drug solution are added, the corrosion rate is reduced to $47.27 \mathrm{mdd}$ and the IE is found to be $20 \%$ due to the antagonistic effect of $\mathrm{Cl}^{-}$ions. Upon addition of various concentrations (60 ppm, $100 \mathrm{ppm}, 140 \mathrm{ppm}$ and $180 \mathrm{ppm}$ ) of MZ drug, IE increases due to the complex $\left(\mathrm{Fe}^{2+}\right.$ - active principle in $\mathrm{MZ}$ drug) formation on the metal surface. When $\mathrm{Zn}^{2+}$ is added to the MZ drug, the IE increases to a great extent because of the synergistic effect between the $\mathrm{MZ}-\mathrm{Zn}^{2+}$ system. For 
example, when $10 \mathrm{ppm}$ of $\mathrm{Zn}^{2+}$ are added to $20 \mathrm{ppm}$ of $\mathrm{MZ}$ drug, the IE increases from $20 \%$ to $48 \%$. However, it is observed that when the concentration of $\mathrm{Zn}^{2+}$ increases from $10 \mathrm{ppm}$ to $50 \mathrm{ppm}$, the IE increases from $57 \%$ to $84 \%$. Experimental results proved that the best inhibitor system for mild steel consists of $60 \mathrm{ppm}$ of $\mathrm{Cl}^{-}+140 \mathrm{ppm}$ of $\mathrm{MZ}$ drug $+50 \mathrm{ppm}$ of $\mathrm{Zn}^{2+}$.

Table 1. Corrosion rates of mild steel immersed in aqueous solution containing $60 \mathrm{ppm}$ of $\mathrm{Cl}^{-}$ion in the absence and presence of inhibitors and the inhibition efficiencies obtained by weight loss method. Inhibitors: metronidazole $(\mathrm{MZ})+\mathrm{Zn}^{2+}$. Immersion period: one day.

\begin{tabular}{|c|c|c|c|c|c|c|c|c|c|}
\hline \multirow[b]{2}{*}{$\begin{array}{l}\mathrm{Cl}^{-} \\
\mathrm{Ppm}\end{array}$} & \multirow[b]{2}{*}{$\begin{array}{l}\text { MZ } \\
\text { ppm }\end{array}$} & \multicolumn{4}{|c|}{ CR( mdd) } & \multicolumn{4}{|c|}{ E \% } \\
\hline & & $\begin{array}{c}\mathrm{Zn}^{2+} \\
0 \mathrm{ppm}\end{array}$ & $\begin{array}{c}\mathrm{Zn}^{2+} \\
10 \mathrm{ppm}\end{array}$ & $\begin{array}{c}\mathrm{Zn}^{2+} \\
25 \mathrm{nvm}\end{array}$ & $\begin{array}{c}\mathrm{Zn}^{2+} \\
50 \mathrm{pnm}\end{array}$ & $\underset{0 \mathrm{pnm}}{\mathrm{Zn}^{2+}}$ & $\begin{array}{c}\mathrm{Zn}^{2+} \\
10 \mathrm{pnm}\end{array}$ & $\begin{array}{c}\mathrm{Zn}^{2+} \\
25 \mathrm{npm}\end{array}$ & $\begin{array}{c}\mathrm{Zn}^{2+} \\
50 \mathrm{ppm}\end{array}$ \\
\hline 60 & 0 & 53.63 & 50.24 & 36.64 & 32.17 & - & 5 & 17 & 23 \\
\hline 60 & 20 & 47.27 & 40.07 & 6.71 & 7.81 & 20 & 48 & 59 & 71 \\
\hline 60 & 60 & 45.30 & 6.57 & 3.15 & 5.20 & 25 & 50 & 61 & 77 \\
\hline 60 & 100 & 42.12 & 5.25 & 2.20 & 3.19 & 28 & 54 & 64 & 80 \\
\hline 60 & 140 & 41.47 & 3.40 & 1.19 & 2.16 & 40 & 57 & 69 & 84 \\
\hline 60 & 180 & 40.24 & 1.29 & 1.11 & 1.40 & 30 & 59 & 62 & -40 \\
\hline
\end{tabular}

Table 2. Influence of the immersion time on the inhibition efficiency of $\mathrm{MZ}-\mathrm{Zn}^{2+}$ system.

\begin{tabular}{lllll|}
\hline Immersion Period, Days & $\mathbf{1}$ & $\mathbf{3}$ & $\mathbf{5}$ & \multicolumn{1}{c|}{$\mathbf{7}$} \\
\hline CR in the absence of the inhibitor, mdd & 53.63 & 26.61 & 24.22 & 20.45 \\
CR in the presence of the inhibitor, mdd & 40.70 & 54.24 & 56.30 & 58.20 \\
IE (\%) & 84 & 72 & 65 & 44 \\
& & & & \\
\hline
\end{tabular}

Influence of the immersion time on the inhibition efficiency of $M Z-\mathrm{Zn}^{2+}$ system

The influence of the immersion time on the inhibition efficiency of the $\mathrm{Zn}^{2+}-\mathrm{MZ}$ system is given in Table 2. It is observed that as the duration of immersion increases, the inhibition efficiency decreases. This is due to the fact that as the time of immersion increases, the protective film formed on the metal surface is not able to withstand the attack of $\mathrm{Cl}^{-}$. The inhibitive film is broken and hence the IE decreases $[16,17]$.

\section{Influence of $\mathrm{pH}$ on IE of metrinidazole $-\mathrm{Zn}^{2+}$ system}

It is seen from Table 3 that at $\mathrm{pH} 7$, the metronidazole (MZ) (140ppm) $-\mathrm{Zn}^{2+}$ (50ppm) and $\mathrm{Cl}^{-}(60 \mathrm{ppm})$ system has $84 \%$ IE. When $\mathrm{pH}$ is lowered to 5 by addition of dilute sulphuric acid, the IE decreased to $75 \%$. This is due to the fact that when the acid is added the protective film is broken by the aggressive $\mathrm{H}^{+}$ ions present in the acid. When the $\mathrm{pH}$ is increased to 9.2 by addition of diluted sodium hydroxide solution, the IE increased to $80 \%$ when compared to an acidic medium. However, this $80 \%$ IE in basic medium ( $\mathrm{pH} 9.2$ ) is lower than the IE of $84 \%$ in neutral medium. This is due to the fact that when $\mathrm{NaOH}$ is added, a 
portion of $\mathrm{Zn}^{2+}$ is precipitated as $\mathrm{Zn}(\mathrm{OH})_{2}$ in the bulk of the solution and hence not available for the complex formation.

Table 3. Influence of various $\mathrm{pH}$ values on the $\mathrm{IE}$ of $\mathrm{MZ}-\mathrm{Zn}^{2+}$ system.

\begin{tabular}{|cccccc|}
\hline $\mathbf{C l}^{-} \mathbf{~ p p m}$ & MZ $\mathbf{~ p m}$ & $\mathbf{Z n}^{2+} \mathbf{p p m}$ & $\mathbf{p H}$ & $\mathbf{C R}$ mdd & IE \% \\
\hline 60 & 0 & 0 & 5 & 56.74 & - \\
60 & 140 & 50 & 5 & 25.00 & 75 \\
60 & 0 & 0 & 7 & 53.63 & - \\
60 & 140 & 50 & 7 & 10.94 & 84 \\
60 & 0 & 0 & 9.2 & 50.36 & - \\
60 & 140 & 50 & 9.2 & 8.27 & 80 \\
\hline
\end{tabular}

\section{Analysis of potentiodynamic polarization study}

Potentiodynamic polarization studies have been used to detect the formation of protective film on the metal surface [18-26] .The potentiodynamic polarization curves of mild steel immersed in various test solutions are shown in Fig. 2. The corrosion parameters, namely corrosion potential $\left(\mathrm{E}_{\mathrm{corr}}\right)$, Tafel slopes $\left(\mathrm{b}_{\mathrm{c}}\right.$ $=$ cathodic; $\mathrm{b}_{\mathrm{a}}=$ anodic $)$, corrosion current $\left(\mathrm{I}_{\text {corr }}\right), \mathrm{Rp}, \mathrm{C}_{\text {rate }}$ and IE are given in Table 4. When mild steel is immersed in aqueous solution containing $60 \mathrm{ppm}$ of $\mathrm{Cl}^{-}$ ion, the corrosion potential is $-515 \mathrm{mV}$ vs. SCE. The formulation consisting of $140 \mathrm{ppm}$ of $\mathrm{MZ}$ and $50 \mathrm{ppm}$ of $\mathrm{Zn}^{2+}$ shifts the corrosion potential to $-605 \mathrm{mV}$ vs. SCE suggesting that the reaction is predominantly catholically controlled. The $\mathrm{Rp}$ value increases from $1511 \mathrm{ohm} \mathrm{cm}^{2}$ to $7073 \mathrm{ohm} \mathrm{cm}^{2}$. This suggests that a protective film is formed on the metal surface. Further, the corrosion current decreases from $3.60 \times 10^{-5} \mathrm{~A} / \mathrm{cm}^{2}$ to $9.9 \times 10^{-6} \mathrm{~A} / \mathrm{cm}^{2}$. The IE calculated from corrosion current data is $73 \%$. This value is lower than the IE obtained by weight loss method (84\%). The discrepancy may be explained by the fact that in electro chemical process, the instantaneous corrosion current is measured. However, in the case of weight loss method, IE is calculated after a long time. The protective film formed is strengthened as the duration of immersion increases. In the presence of inhibitors, the cathodic and anodic Tafel slopes are more or less equal. This indicates that the formulation consisting of $\mathrm{MZ}-\mathrm{Zn}^{2+}$ system as a mixed type of inhibitor controlled by both the cathodic and anodic reaction to an equal extent. In several investigations, acidic media of some drugs such as Albendazole and Ketorol [27, 28] has been reported as a mixed type but predominantly cathodic inhibitor.

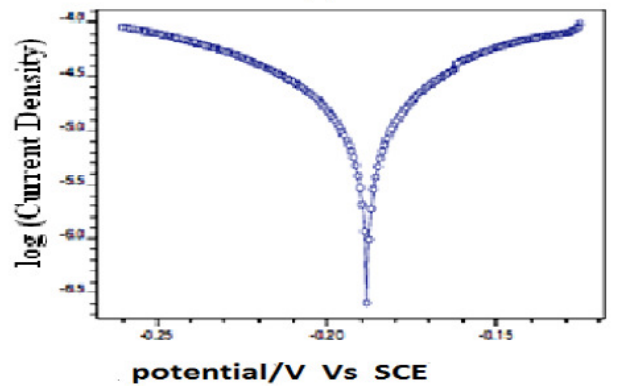

a)

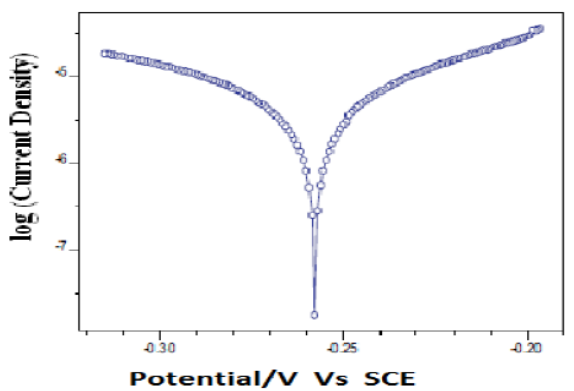

b)

Figure 2. Polarisation curves of mild steel immersed in various test solutions. (a) $\mathrm{Cl}^{-}$ (60 ppm). (b) $\mathrm{Cl}^{-}(60 \mathrm{ppm})+\mathrm{MZ}(140 \mathrm{ppm})+\mathrm{Zn}^{2+}(50 \mathrm{ppm})$. 
Table 4. Corrosion parameters of mild steel immersed in MZ drug obtained from polarization study (Tafel Polarization).

\begin{tabular}{|c|c|c|c|c|c|c|c|c|c|}
\hline $\begin{array}{l}\mathrm{Cl}^{-} \\
\mathrm{ppm}\end{array}$ & $\begin{array}{l}\text { MZ } \\
\text { ppm }\end{array}$ & $\begin{array}{l}\mathrm{Zn}^{2+} \\
\mathrm{ppm}\end{array}$ & $\begin{array}{c}\mathbf{E}_{\text {corr }} \\
(\mathrm{mV} \text { vs. SCE) }\end{array}$ & $\begin{array}{c}\mathbf{b}_{\mathbf{c}} \\
\text { (mV/decade }\end{array}$ & $\begin{array}{c}\mathbf{b}_{\mathbf{a}} \\
\text { (mV/decade) }\end{array}$ & $\begin{array}{l}\mathbf{I}_{\text {corr }} \\
\mathrm{N} / \mathrm{cm}^{2}\end{array}$ & $\begin{array}{c}\mathbf{R p} \\
\left(\mathrm{ohm} \mathrm{cm}^{2}\right)\end{array}$ & $\begin{array}{c}\mathrm{C}_{\text {rate }} \\
\text { mdd }\end{array}$ & IE \% \\
\hline 60 & 0 & 0 & -515 & 75 & 67 & $3.60 \times 10^{-5}$ & 1511 & $1.495 \times 10^{-2}$ & - \\
\hline 60 & 0 & 50 & -548 & 128 & 88 & $1.79 \times 10^{-5}$ & 4491 & $7.428 \times 10^{-2}$ & 50 \\
\hline 60 & 140 & 0 & -556 & 95 & 87 & $1.33 \times 10^{-5}$ & 4956 & $5.536 \times 10^{-2}$ & 63 \\
\hline 60 & 140 & 50 & -605 & 90 & 82 & $9.9 \times 10^{-6}$ & 7073 & $4.115 \times 10^{-2}$ & 73 \\
\hline
\end{tabular}

\section{Analysis of AC impedance study}

The impedance behavior of mild steel in aqueous solution with and without addition of various concentrations of metronidazole (MZ) is presented as complex impedance plot (Nyquist plot) in Fig 3(a) \& (b). The appearance of a single semi-circle shows the single charge transfer process during dissolution which is unaffected by the presence of the inhibitor molecule. Deviation from perfect circular shape is often referred to the frequency dispersion of interfacial impedance.

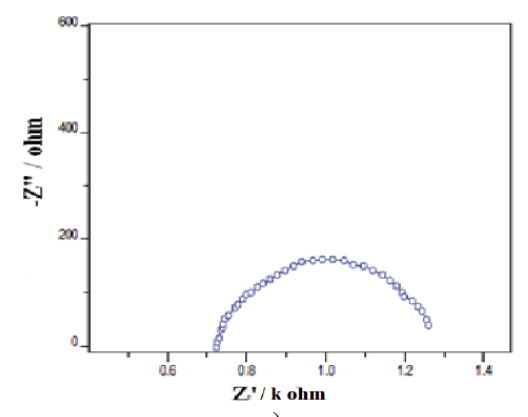

a)

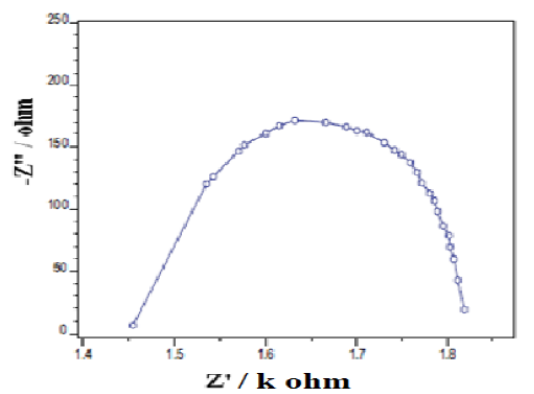

b)

Figure 3. AC impedance spectra of steel immersed in various test solutions. (a) $\mathrm{Cl}^{-} 60$ ppm. (b) $\mathrm{Cl}^{-}(60 \mathrm{ppm})+\mathrm{MZ}(140 \mathrm{ppm})+\mathrm{Zn}^{2+}(50 \mathrm{ppm})$.

This anomalous behavior is generally attributed to the inhomogeneity of the metal surface arising from surface roughness or interfacial phenomena [29-31]. It is seen that the addition of inhibitor, increases the value of charge transfer resistance $\left(R_{c t}\right)$ and reduces the double layer capacitance $\left(C_{\mathrm{dl}}\right)$. A depressed semicircle is mostly referred to as frequency dispersion which could be attributed to different physical phenomena such as roughness and inhomogeneities of the solid surfaces, impurities, grain boundaries and distribution of the surface active sites [32]. The decrease in $C_{\mathbf{d l}}$ is attributed to increase in the thickness of the electronic double layer [33]. The increase in $R_{\text {ct }}$ value is ascribed to the formation of a protective film on the metal/solution interface [34]. These observations suggest that metronidazole drug molecules function by adsorption at metal surface thereby causing the decrease in $C_{\mathbf{d l}}$ values and increase in $R_{\mathbf{c t}}$ values. The charge transfer resistance $\left(R_{\mathbf{c t}}\right)$ and the interfacial double layer capacitance $\left(\mathrm{C}_{\mathbf{d l}}\right)$ derived from these curves are given in Table 5. In this study, when mild steel is immersed in aqueous solution containing $60 \mathrm{ppm} \mathrm{of} \mathrm{Cl}^{-}$ion, the $R_{t}$ value is $678 \mathrm{ohm} \mathrm{cm}^{2}$ and the $C_{\mathrm{dl}}$ value is $9.53 \times 10^{-5} \mathrm{~F} / \mathrm{cm}^{2}$. When MZ drug and $\mathrm{Zn}^{2+}$ are added, the $\mathrm{R}_{\mathrm{t}}$ value increases from $678 \mathrm{ohm} \mathrm{cm}^{2}$ to 1192 ohm $\mathrm{cm}^{2}$ and $\mathrm{C}_{\mathrm{dl}}$ decreases from $9.53 \times 10^{-5} \mathrm{~F} / \mathrm{cm}^{2}$ to $1.71 \times 10^{-5} \mathrm{~F} / \mathrm{cm}^{2}$. This 
suggests that a protective film is formed on the surface of the metal. This accounts for the good IE of MZ- $\mathrm{Zn}^{2+}$ system.

Table 5. Corrosion parameters of mild steel immersed in $\mathrm{MZ}$ drug obtained from AC impedance study.

\begin{tabular}{|ccccc|}
\hline $\mathbf{C l}^{-} \mathbf{p p m}$ & $\mathrm{MZ}$ ppm & $\mathrm{Zn}^{2+} \mathbf{p p m}$ & $\mathbf{R}_{\mathrm{t}} \mathbf{O h m ~ \mathbf { ~ m } ^ { 2 }}$ & $\mathbf{C}_{\mathrm{dl}} \mathbf{F} / \mathrm{cm}^{2}$ \\
\hline 60 & 0 & 0 & 678 & $9.53 \times 10^{-5}$ \\
60 & 140 & 50 & 1192 & $1.71 \times 10^{-5}$ \\
\hline
\end{tabular}

\section{Analysis of FTIR spectra}

The active principle in metronidazole (MZ) is given as follows.

a) The FTIR spectrum of pure metronidazole (MZ) is shown in Fig. 4 (a). The saturated carbon of $\mathrm{C}-\mathrm{H}$ stretching frequency appears at $2845.13 \mathrm{~cm}^{-1}$. The alkene mono substituted $\mathrm{C}-\mathrm{H}$ stretching frequency appears at $3098.78 \mathrm{~cm}^{-1}$. The band due to intra molecular hydrogen bonding of O-H stretching appears at $3218.37 \mathrm{~cm}^{-1}$. The peak at $1533.47 \mathrm{~cm}^{-1}$ is due to the $\mathrm{C}-\mathrm{NO}_{2}$. The $\mathrm{C}=\mathrm{N}$ stretching frequency appears at $1654.25 \mathrm{~cm}^{-1}$. Thus the structure of metronidazole is confirmed by FTIR spectrum.

b) The FTIR spectrum of the protective film formed on the surface of the metal after immersion in the solution containing $60 \mathrm{ppm}$ of $\mathrm{Cl}^{-}$ion, $50 \mathrm{ppm}$ of $\mathrm{Zn}^{2+}$ and $140 \mathrm{ppm}$ of metronidazole (MZ) is shown in Fig 4 (b). It is found that the saturated carbon of $\mathrm{C}-\mathrm{H}$ stretching frequency has shifted from 2845.13 to $2834.87 \mathrm{~cm}^{-1}$. The alkene carbon of $\mathrm{C}-\mathrm{H}$ stretching frequency has shifted from $3098.78 \mathrm{~cm}^{-1}$ to $3097.81 \mathrm{~cm}^{-1}$. The intra molecular hydrogen bonding of $\mathrm{O}-\mathrm{H}$ stretching has shifted from $3218.37 \mathrm{~cm}^{-1}$ to $3216.44 \mathrm{~cm}^{-1}$. The $\mathrm{C}-\mathrm{NO}_{2}$ stretching has shifted from $1533.47 \mathrm{~cm}^{-1}$ to $1531.52 \mathrm{~cm}^{-1}$. The $\mathrm{C}=\mathrm{N}$ stretching frequency shifts from $1654.25 \mathrm{~cm}^{-1}$ to $1651.14 \mathrm{~cm}^{-1}$. These shifts confirm the formation of $\mathrm{Fe}^{2+}-\mathrm{MZ}$ complex on the anodic sites on the metal surface. The peak at $1365.66 \mathrm{~cm}^{-1}$ is due to $\mathrm{Zn}(\mathrm{OH})_{2}$ formed on the cathodic sites of the metal surface $[35,36]$.

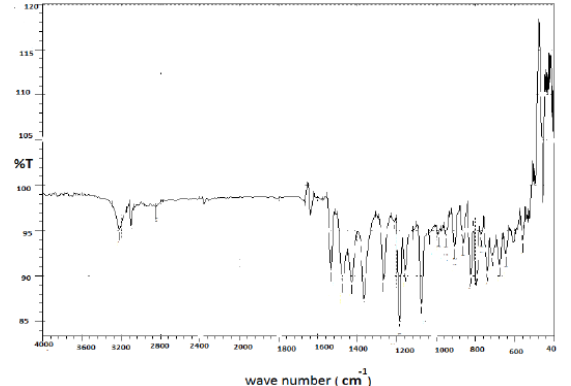

a)

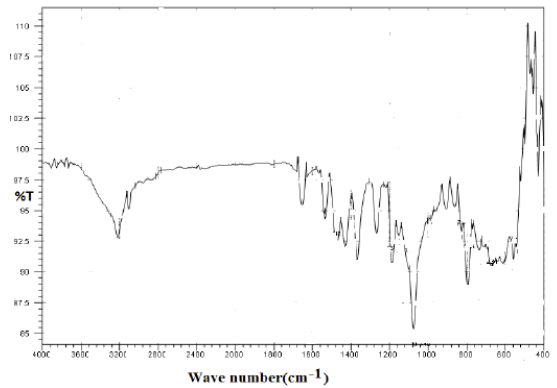

b)

Figure 4. (a) FTIR spectrum of pure metronidazole; (b) FTIR spectrum of the film formed on mild steel surface after immersion in a solution containing $\mathrm{Cl}^{-}$(60 ppm) $+\mathrm{MZ}(140 \mathrm{~m})+\mathrm{Zn}^{2+}(50 \mathrm{ppm})$. 
This confirms the presence of $\mathrm{Fe}^{2+}-\mathrm{MZ}$ complex on the metal surface. $\mathrm{Fe}^{2+}$ has coordinated with the $\mathrm{O}$-atom of the $-\mathrm{OH}$ group, $\mathrm{N}$ atom of the hetero cyclic ring and $\mathrm{O}$-atom of the $-\mathrm{NO}_{2}$ group. The formation of $\mathrm{Fe}^{3+}$ cannot be ruled out.

\section{Conclusions}

The present study leads to the following conclusions:

* the inhibition efficiency (IE) of metronidazole ( $\mathrm{MZ}$ ) $-\mathrm{Zn}^{2+}$ system in controlling corrosion of mild steel in aqueous solution containing $60 \mathrm{ppm}$ of $\mathrm{Cl}^{-}$ion has been evaluated by weight loss method. Weight loss study reveals that the formulation consisting of $140 \mathrm{ppm}$ of $\mathrm{MZ}$ and $50 \mathrm{ppm}$ of $\mathrm{Zn}^{2+}$ has $84 \%$ inhibition efficiency;

* polarization study reveals that this system functions as a mixed type inhibitor, controlling the cathodic and anodic reaction to an equal extent;

*AC impedance study reveals that a protective film is formed on the metal surface;

* the FTIR spectra reveal the formation of a protective film consisting of $\mathrm{Fe}^{2+}$ metronidazole $(\mathrm{MZ})$ complex and $\mathrm{Zn}(\mathrm{OH})_{2}$.

\section{References}

1. Ali SA, Saeed MT, Rahman SV. Corros Sci. 2003;45:253-266.

2. Lagrenee M, Mernari B, Bouanis M, Traisnel M, Bentiss F. Corros Sci. 2002;44:573-588.

3. Quraishi MA, Sardar R. Corrosion. 2002;58.748-755.

4. Quraishi MA, Athar M, Ali H. Br Corrosion J. 2002;37:155-163.

5. Quraishi MA, Ansari FA. J Appl Electrochem. 2003;33:233-238.

6. Quraishi MA, Khan S. J Appl Electrochem. 2006;36:539-544.

7. Shukla SK, Quraishi MA. Mater Chem Phys. 2010;120:142-147.

8. Shukla SK, Quraishi MA. Corros Sci. 2010;52:314-321.

9. Morad MS. Corros. Sci. 50 (2008) 436-448.

10. Shukla SK, Quraishi MA. Corros Sci. 2009;51:1007-1011.

11. Shukla SK, Singh AK, Ahamed I, Quraishi MA. Mater Lett. 2009;63:819-822.

12. Abdallah M. Corros Sci. 2004;46:1981-1986.

13. Naqvi I, Saleemi AR, Naveed S. Int J Electrochem Sci. 2011;6:146-161.

14. Abdallah M. Corros Sci. 2004;46:1981-1986.

15. Al-Sebea N. AJPS. 2008;5:16-25.

16. Anbarasi CM, Rajendran S. J Electrochem Soc India. 2011;60:115-122.

17. Sangeetha M, Rajendran S, Sathiyabama J, Krishnaveni A, Shanthy P, Manimaran N, Shyamaladevi B. Port Electrochim Acta. 2011;29:429-444.

18. Sherine B, Nasser AJA, Rajendran S. Int J Eng Sci Tech. 2010;2:341-357.

19. Thangam YY, Kalanith M, Anbarasi CM, Rajendran S. Arabian J Sci Eng. 2009;34:49-60.

20. Sathiyabama J, Rajendran S, Sundari JJ, Shyamaladevi B. J Eng Sci Tech Rev. 2010;3:27-31.

21. Narayanasamy B, Rajendran S. Prog Org Coat. 2010;67:246-254.

22. Rajendran S, Sumithra P, Devi BS, Jeyasundari J. Zastita Materijala. 2009;50:223-226.

23. Sherine HB, Mani RK, Rajendran S. J Electrochem Soc India. 2008;57:67-73. 
24. Rajendran S, Uma V, Krishnaveni A, Jeyasundari J, Shyamaladevi B, Manivannan M. Arabian J Sci Eng. 2010;34:147-158.

25. Kanimozhi SA, Rajendran S. Arabian J Sci Eng. 2009;35:41-52.

26. Rathish RJ, Rajendran S, Christy JL, Devi BS, Johnmary S, Manivannan M, Rajam K, Rengan P. Open Corros J. 2010;3:38-44.

27. Ahamed I, Prasad R, Ebenso EE, Quraishi MA, Int J Electrochem. Sci. 2012;7:3436-3452.

28. Quraishi MA, Sugheer, Ebenso EE. Int J Electrochem Sci. 2012;7:9920-9932.

29. Shih H, Mansfeld H. Corros Sci. 1989;29:1235-1240.

30. Mansfeld M, Martinez S. J Appl Electrochem. 2003;33:1137-1142.

31. Elayyachy M, Idrissi AE, Hammouti B. Corros Sci. 2006;48:2470-2479.

32. Singh A, Ebenso EE, Quraishi MA. Int J Electrochem Sci. 2012;7:4766-4779.

33. Hosseini MG, Ehteshamzadeh M, Shahrabi T. Electrochim Acta. 2007;52:36803685.

34. Bentiss F, Traisnel M, Laggrenee M. Corros Sci. 2000;42:127-146.

35. Francis RMS, Bassler GC, Morrill TC. Spectrometric identification for organic compounds. New York: John Wiley \& Sons, 1986.

36. Sekine I, Hirakawa Y. Corrosion 1986;42:272-277. 